\title{
Rola sprzedaży bezpośredniej w okresie spowolnienia gospodarczego w Polsce (na przykładzie Systemów Informacji Prawnej)
}

\section{The role of direct sales during economic downturn in Poland (based on the example of Computer - Assisted Legal Research Systems)}

\begin{abstract}
Streszczenie: Sprzedaż bezpośrednia w szerokim znaczeniu, rozumiana jako wykonana przez jedną osobę w stosunku do drugiej prezentacja produktu połączona z propozycją jego zakupu, znana jest na świecie od tysiącleci. Do celów niniejszego opracowania posłużono się znacznie węższym znaczeniem terminu „sprzedaż bezpośrednia”, kiedy przedstawiciel jednej firmy (producenta) dokonuje prezentacji produktu najczęściej w siedzibie drugiej firmy (ang. B2B - Business to Business). Taki sposób dystrybucji towarów i usług na szerszą skalę pojawił się w Polsce po przełomie politycznym i gospodarczym w 1989 roku. Dominująca rola własnej sieci przedstawicieli handlowych wynika przede wszystkim ze złożonej funkcjonalności produktu i związanej z tym potrzeby bezpośredniego przedstawienia klientowi wartości merytorycznych produktu i korzyści związanych z jego użytkowaniem. W tym celu przedstawiciel handlowy musi pełnić funkcję konsultanta, a więc oprócz typowych umiejętności handlowych powinien dysponować odpowiednią wiedzą z zakresu dyscypliny, do której nawiązuje dany produkt. Drugim istotnym czynnikiem determinującym proces sprzedaży jest cena towaru lub usługi. Im droższy produkt, tym trudniej jest go sprzedać bez osobistego kontaktu z potencjalnym odbiorcą. Dużym atutem sprzedaży bezpośredniej jest jej efektywność. Odpowiednio przeszkoleni konsultanci mają indywidualny kontakt z klientem oraz możliwość bezpośredniej perswazji i negocjacji, co znacznie zwiększa szansę sprzedaży. Celem niniejszego opracowania jest przedstawienie roli, jaką może odgrywać proces sprzedaży bezpośredniej w trudnym otoczeniu rynkowym, w szczególności przy zmniejszającej się chęci potencjalnych odbiorców do zakupów.
\end{abstract}

\begin{abstract}
Direct sales understood in the broad sense of the word as product presentation coupled with the offer to sell made by one person to another, has been known in the world for millennia. For the purpose of this study a narrower meaning of the term "direct sales" was adopted. Namely, a representative of one company (manufacturer) usually makes a presentation of a product in another company's headquarters (B2B - Business to Business). This type of distribution of goods and services appeared in Poland on a large scale at the time of political and economic transformation of 1989. The dominant role
\end{abstract}


of own network of sales representatives is primarily due to complex functionality of the product and the related necessity of direct presentation at the client's, aimed at presenting the product itself along with benefits associated with its use. To be able to do so, a sales representative must act as a consultant. Therefore, in addition to typical business skills they should have adequate knowledge of the discipline the product represents. Another important factor that determines the sales process is the price of goods or services. The more expensive the product, the harder it is to sell without personal contact with a potential customer. The effectiveness of direct sales is its greatest advantage. Properly trained consultants have a personal contact with the customer and the ability of direct persuasion and negotiation which significantly increases the chances of selling. The purpose of this paper is to present the role a direct sales process may play in a challenging market environment, in particular in the situation of decreasing willingness of potential customers to buy.

Słowa kluczowe: spowolnienie gospodarcze; sprzedaż bezpośrednia; System Informacji Prawnej

Keywords: economic downturn; direct sale; Computer-Assisted Legal Research System

\section{WSTĘP}

Dla wszystkich uczestników rynku, a w szczególności dla podmiotów gospodarczych, odpowiednio usystematyzowana informacja prawna jest kluczowa z punktu widzenia podejmowania decyzji, co przekłada się na funkcjonowanie przedsiębiorstw, instytucji państwowych, a także poszczególnych osób fizycznych. W Polsce po okresie transformacji pojawiły się na rynku narzędzia informatyczne (aplikacje), które dały początek obecnie istniejącym i bardzo rozbudowanym systemom informatycznym określanym jako Systemy Informacji Prawnej (SIP). Producentami Systemów Informacji Prawnej są wydawnictwa prawnicze i ekonomiczne, które wydają także liczne publikacje papierowe (komentarze, podręczniki akademickie, poradniki i inne). W odróżnieniu jednak od klasycznych książek papierowych, które sprzedawane są z reguły za pośrednictwem księgarń, SIP dystrybuowane są w sposób bezpośredni poprzez przedstawicieli handlowych danego wydawcy (producenta). Celem niniejszego artykułu jest przedstawienie roli jaką może odgrywać proces sprzedaży bezpośredniej w trudnym otoczeniu rynkowym, w szczególności przy zmniejszającej się chęci potencjalnych nabywców do zakupów w okresie spowolnienia gospodarczego. Artykuł oparty jest przede wszystkim na wieloletniej obserwacji uczestniczącej.

\section{SPOWOLNIENIE GOSPODARCZE W POLSCE PO ROKU 2008}

W opinii ekonomistów ogólnoświatowy kryzys gospodarczy został zapoczątkowany przez załamanie się rynku nieruchomości oraz rynku finansowego (ogłoszenie bankructwa przez bank Lehmann Brothers) w 2007 roku. Jego przyczyny miały jednak dużo głębszy charakter, zarówno mikroekonomicznych, jak i makroekonomicznych przemian na rynku światowym, takich jak: długotrwała nierównowaga w handlu między gospodarkami rozwiniętymi a wschodzącymi, utrzymywanie realnych stóp procentowych na niskim poziomie, niedociągnięcia i błędy nadzoru finansowego w wielu krajach (Rachwał, 2011). Stosowane 
w Polsce rozwiązania, mimo wynikającego z nich dużego poziomu kontroli państwa nad finansami, okazały się skuteczniejsze od pozostałych, wybranych przez inne państwa, dzięki czemu skutki gospodarcze kryzysu w Polsce były mniej odczuwalne niż w innych krajach (Gorzelak, 2009). W przypadku podstawowego wskaźnika, jakim jest PKB, po 2008 roku nie zaobserwowano jego spadku, jednakże jego wzrost został wyhamowany. Jednym ze wskaźników, który jest wrażliwy na fluktuacje gospodarki w ujęciu globalnym, jest produkcja sprzedana przemysłu. W Polsce zaobserwowano spadek produkcji sprzedanej przemysłu w latach 2008-2009 w porównaniu do poziomu z roku 2005 (Rachwał, 2011). Odbicie nastąpiło już w roku 2010, zaś sam spadek był mniejszy niż w wielu innych krajach europejskich. Dzięki zdywersyfikowanej strukturze gospodarczej największą odpornością na kryzys powinny wykazywać się ośrodki metropolitalne. W przypadku obszarów pozametropolitalnych najbardziej zagrożone są ośrodki uzależnione od jednej branży lub zakładu (Gorzelak, 2009).

Kryzys rozpatrywany jest w bardzo wielu aspektach, a jednym z ważniejszych, choć często pomijanych, jest jego aspekt społeczny lub - jak wskazuje T.T. Brzozowski (Brzozowski, 2011) - filozoficzno-społeczny. Pomiędzy kwestiami statystycznymi, takimi jak załamanie się poziomu produkcji, liczba bankructw, zmiany we wskaźnikach bezrobocia i inwestycji, kryją się ważne dla przeciętnego człowieka niepokojące zjawiska, takie jak: kurczący się rynek pracy i konieczność dostosowywania się do szybko zmieniających się warunków, niepewność jutra, walka o byt.

\section{SprzedAż BeZPośrednia w Polsce}

Sprzedaż bezpośrednia w szerokim znaczeniu, rozumiana jako wykonana przez jedną osobę w stosunku do drugiej prezentacja produktu połączona z propozycją jego zakupu, znana jest na świecie od tysiącleci (Waszczyk i Rodacki, 2005). Według Polskiego Stowarzyszenia Sprzedaży Bezpośredniej (PSSB, 2013) przez sprzedaż bezpośrednią należy rozumieć oferowanie towarów i usług bezpośrednio konsumentom poprzez kontakty indywidualne, zazwyczaj w domu klienta, miejscu pracy lub w innych miejscach poza stałymi punktami sprzedaży detalicznej. Jest to forma sprzedaży detalicznej poza siecią sklepową. W PSSB skupionych jest ponad 70\% ogółu przedsiębiorstw zajmujących się sprzedażą bezpośrednią konsumentom w Polsce. W 2012 roku zdecydowanie dominowała sprzedaż kosmetyków (ponad 70\%). Pozostały asortyment to: suplementy diety, AGD, odzież i akcesoria, usługi oraz żywność i napoje.

Okres spowolnienia gospodarczego po 2008 roku nie znajduje odzwierciedlenia w branży sprzedaży bezpośredniej. Kiedy produkcja sprzedana przemysłu w Polsce notowała wyraźny spadek, a tempo wzrostu PKB zaczynało słabnąć, branża sprzedaży bezpośredniej wkroczyła w okres prawdziwego boomu. W 2009 roku skokowo wzrosła liczba sprzedawców bezpośrednich (wzrost o 17\% w stosunku do poziomu z roku 2008) i w kolejnych latach utrzymywała się na bardzo wysokim poziomie, osiągając apogeum w 2012 roku - ok. 900 tys. osób zajmujących się sprzedażą bezpośrednią (ryc. 1). 


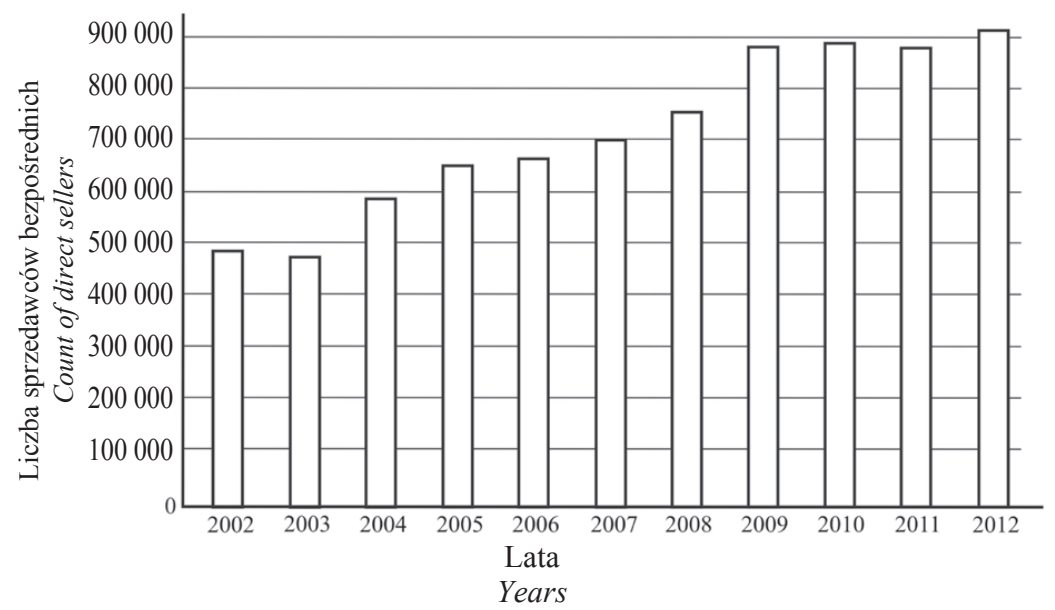

Ryc. 1. Liczba sprzedawców bezpośrednich (rynek konsumencki) w Polsce Żródło: PSSB (2013)

Skokowy wzrost zatrudnienia w ramach procesu sprzedaży bezpośredniej przełożył się także na wzrost obrotów w całej branży, w szczególności w 2010 roku. W 2012 roku przedsiębiorstwa skupione w PSSB odnotowały obroty o wartości 2,7 mld zł (ryc. 2). Według World Federation of Direct Selling Associations (WFDSA), łączna wartość detalicznej sprzedaży bezpośredniej na świecie w 2011 roku wyniosła ponad 153,7 mld dol., czyli prawie o $10 \%$ więcej niż rok wcześniej, a liczba sprzedawców wzrosła o $7 \mathrm{mln}$ w porównaniu z 2010 rokiem.

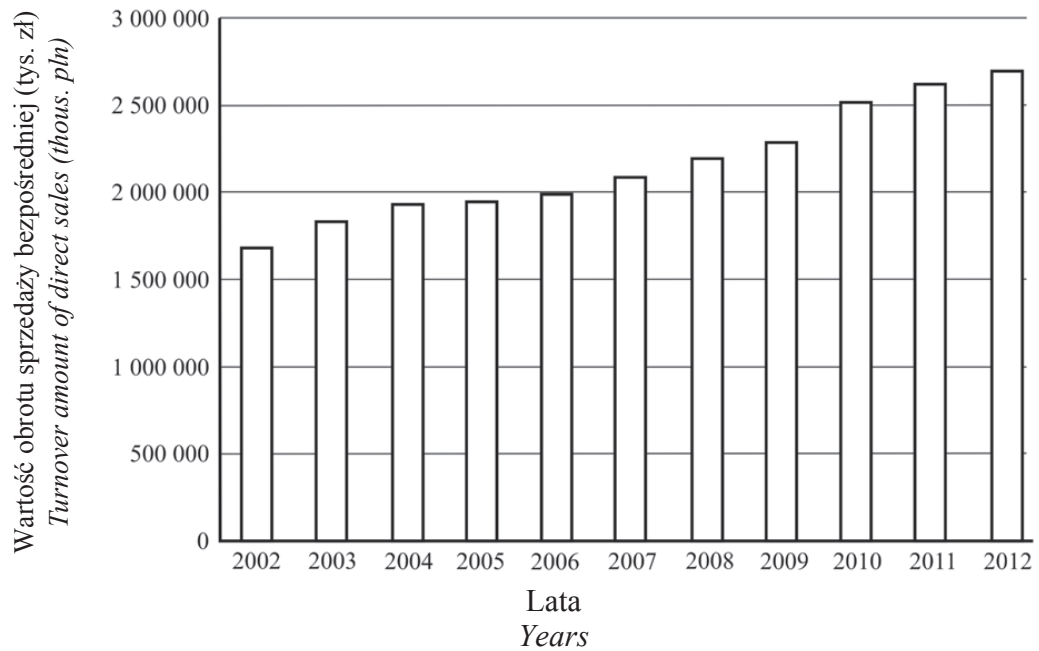

Ryc. 2. Obroty (w tys. zł) przedsiębiorstw skupionych w ramach PSSB w latach 2002-2012 Źródło: PSSB (2013) 
Sukces sprzedaży bezpośredniej w okresie spowolnienia gospodarczego, zarówno na świecie, jak i w Polsce, można tłumaczyć m.in. tym, że w branży tej stosunkowo łatwo można znaleźć zatrudnienie. Dlatego też wiele osób, które utraciły pracę wskutek spowolnienia gospodarczego, przeszło do sprzedaży bezpośredniej. Obserwowane jest także zjawisko szukania dodatkowych możliwości zarobku przez osoby mające stałe zatrudnienie. W okresie kryzysu takie zjawisko szczególnie przybiera na sile. Poza tym dla wielu osób sprzedaż bezpośrednia to pierwsza praca. Do czynników, które przyciągają potencjalnych kandydatów do sprzedaży bezpośredniej, można zaliczyć: pracę na własny rachunek, elastyczny czas pracy, samodzielne budowanie ścieżki kariery, łatwość startu - firmy oferują bezpłatne szkolenia, a także tzw. zestawy startowe po symbolicznych cenach. Od dawna już firmy sprzedaży bezpośredniej nie stawiają na typowe akwizytorstwo. Większość sprzedawców zdobywa klientów z polecenia, rozszerzając stopniowo krąg odbiorców. Wtedy mogą budować sieć współpracowników, zarabiając też na prowizji od ich obrotów.

Poza przedstawionym powyżej modelem sprzedaży bezpośredniej, opartym przede wszystkim na relacjach kontrahent - konsument (ang.: B2C - Business to Consumer), powszechnie występuje także model oparty na relacjach kontrahent - kontrahent (ang.: B2B Business to Business). Wiele firm funkcjonujących na konkurencyjnym rynku posiada przedstawicieli handlowych (konsultantów), którzy na spotkaniach handlowych u potencjalnych klientów prezentują towary lub usługi, a następnie negocjują warunki ich sprzedaży. Taki sposób dystrybucji towarów i usług na szerszą skalę w Polsce pojawił się po przełomie politycznym i gospodarczym w 1989 roku. Przedsiębiorstwa najczęściej decydują się na wykorzystanie modelu sprzedaży opartego na własnej sieci przedstawicieli handlowych wtedy, kiedy:

- występuje złożona funkcjonalność oferowanych przez firmę produktów i związana z tym potrzeba bezpośredniego przedstawienia klientowi wartości merytorycznych produktu oraz korzyści związanych z jego użytkowaniem; przedstawiciel handlowy pełni w tym przypadku funkcję konsultanta i powinien dysponować odpowiednią wiedzą z danej dziedziny,

- cena towaru lub usługi jest wysoka; im droższy produkt, tym trudniej go sprzedać bez osobistego kontaktu z potencjalnym odbiorcą,

- firmy wprowadzają na rynek innowacyjne produkty pod nierozpoznawalną marką; występuje wtedy ze strony potencjalnych nabywców tzw. opór przed zmianami i rolą przedstawiciela handlowego jest zminimalizowanie jego efektu, np. poprzez umożliwienie przetestowania produktu.

Często się zdarza, że firmy oferujące towary i usługi tego samego typu wykorzystują odmienne metody ich dystrybucji. Wynika to m.in. z tego, że decydenci przenoszą pewne modele z poprzednich miejsc pracy, a także mają prywatne preferencje dotyczące stosowanych metod, co nie zawsze jest merytoryczne uzasadnione. Należy pamiętać, że w czasach spowolnienia gospodarczego przedsiębiorstwa starają się minimalizować swoje wydatki, dlatego też metody dystrybucji towarów i usług oparte na inicjatywie potencjalnego nabywcy nie sprawdzają się. W czasach kryzysu ekonomicznego rośnie znaczenie modelu sprzedaży bezpośredniej. M. Makowska (Makowska, 2010) podkreśla, że dużym atutem sprzedaży bezpośredniej jest jej efektywność. Odpowiednio przeszkoleni dystrybutorzy mają indywidualny kontakt z klientem, możliwość bezpośredniej perswazji i negocjacji, co znacznie zwiększa szansę sprzedaży. 
RozwinięCIE Pojęcia „System Informacji Prawnej”

Pojęcie „System Informacji Prawnej” (SIP) definiowane jest w literaturze naukowej w ramach dziedziny wiedzy określanej jako informatyka prawnicza. Według G. Wierczyńskiego i W.R. Wiewiórowskiego (Wierczyński, Wiewiórowski, 2012: 75-76), przez SIP należy rozumieć prawnicze programy horyzontalne, czyli takie, których bazy mają z założenia obejmować jak najszerszy zakres tematyki prawnej, dążąc do uwzględnienia całości informacji prawnej i prawniczej w Polsce. Inny cel niż SIP realizowany jest w programach wertykalnych. Autorzy tej grupy baz nie przedstawiają całości prawa, lecz wybierają zeń pewien wycinek, prezentując program komputerowy, którego zamierzeniem jest ujęcie tematyki prawnej w sposób idealnie dopasowany do wymagań danej branży lub danego odbiorcy.

Pojęcie SIP jest często nadużywane przez producentów różnego typu programów i serwisów internetowych. Służy to z reguły podniesieniu rangi danego serwisu, ale powoduje, że termin ten staje się niejasny dla potencjalnych klientów (użytkowników) (Patkowski, 2013: 368). Na początku lat 90. XX wieku powstał pierwszy komercyjny System Informacji Prawnej - SIP Lex. Walka rynkowa podmiotów dostarczających przetworzoną informację prawną wykształciła w Polsce systemy, których zasób informacyjny, możliwości techniczne oraz ergonomia używania pozwalają uznać Polskę za jednego z liderów na rynku podobnego oprogramowania w Europie (Wiewiórowski, 2008: 86).

Systemy Informacji Prawnej odegrały i odgrywają znaczącą rolę w kształtowaniu gospodarki opartej na wiedzy w Polsce. Rola ta nie sprowadza się do znaczącego udziału w PKB naszego kraju (udział ten jest znikomy), ale polega na zbliżeniu wiedzy i informacji do procesów decyzyjnych zarówno w sektorze prywatnym, jak i publicznym. Systemy te w swojej klasycznej formie wyszły poza tradycyjny rynek prawniczy, dając impuls do tworzenia wielu innych narzędzi informatycznych, skierowanych do szerokiego rynku odbiorców. Dzięki tym wszystkim narzędziom informacja prawna, ekonomiczna i biznesowa stała się informacją powszechnie dostępną.

\section{Metody dystrybucj Systemów Informacj Prawnej}

Systemy Informacji Prawnej istnieją na polskim rynku od ok. 20 lat. Nie jest to jeden system, lecz kilka konkurujących ze sobą produktów o bardzo zbliżonej zawartości i jakości wykonania. Biorąc pod uwagę teorię cyklu życia produktu, wydaje się, że Systemy Informacji Prawnej wkraczają powoli w fazę dojrzałości, a ściślej w fazę dojrzałości wzrostowej. Wskazuje na to fakt, iż cały czas występuje wzrost sprzedaży SIP, ale jego tempo zaczyna powoli spadać. Mamy do czynienia także z dużą rzeszą stałych użytkowników SIP, którzy z roku na rok przedłużają zakup aktualizacji/abonamentu i dzięki nim wydawcy mogą znacząco zwiększyć zyskowność sprzedaży. Co prawda, w latach 2005-2007 wystąpiły największe wzrosty sprzedaży SIP w XXI wieku (tab. 1), jednakże związane to było z wejściem na rynek nowych producentów. Taka sytuacja obecnie jest mało prawdopodobna, ponieważ 
wszystkie markowe wydawnictwa prawnicze, które dysponują merytorycznym zapleczem w postaci np. bogatych zbiorów komentarzy, orzecznictwa, porad itp., mają w swojej ofercie także Systemy Informacji Prawnej i/lub wertykalne systemy. Można oczywiście wyobrazić sobie wejście na rynek zupełnie nowego podmiotu, jednakże wymagałoby to ogromnych inwestycji. Systemy Informacji Prawnej zaliczane są do rynku książki i pod względem przekazu merytorycznego należy się z tym faktem zgodzić. W porównaniu jednak do klasycznych książek papierowych, a także w stosunku do e-booków, mamy tutaj zupełnie inny sposób dystrybucji. Książki papierowe sprzedawane są najczęściej za pośrednictwem księgarń, a e-booki poprzez księgarnie internetowe. W obu przypadkach inicjatywa należy do potencjalnego nabywcy. To potencjalny klient musi zadecydować, czy udać się do księgarni, czy też odwiedzić daną stronę internetową. W sytuacji niepewności dotyczącej najbliższej przyszłości, a taką jest niewątpliwie spowolnienie gospodarcze, zarówno przedsiębiorcy, jak i konsumenci, starają się ograniczać zakup dóbr, których nie postrzegają jako niezbędnych do normalnego funkcjonowania.

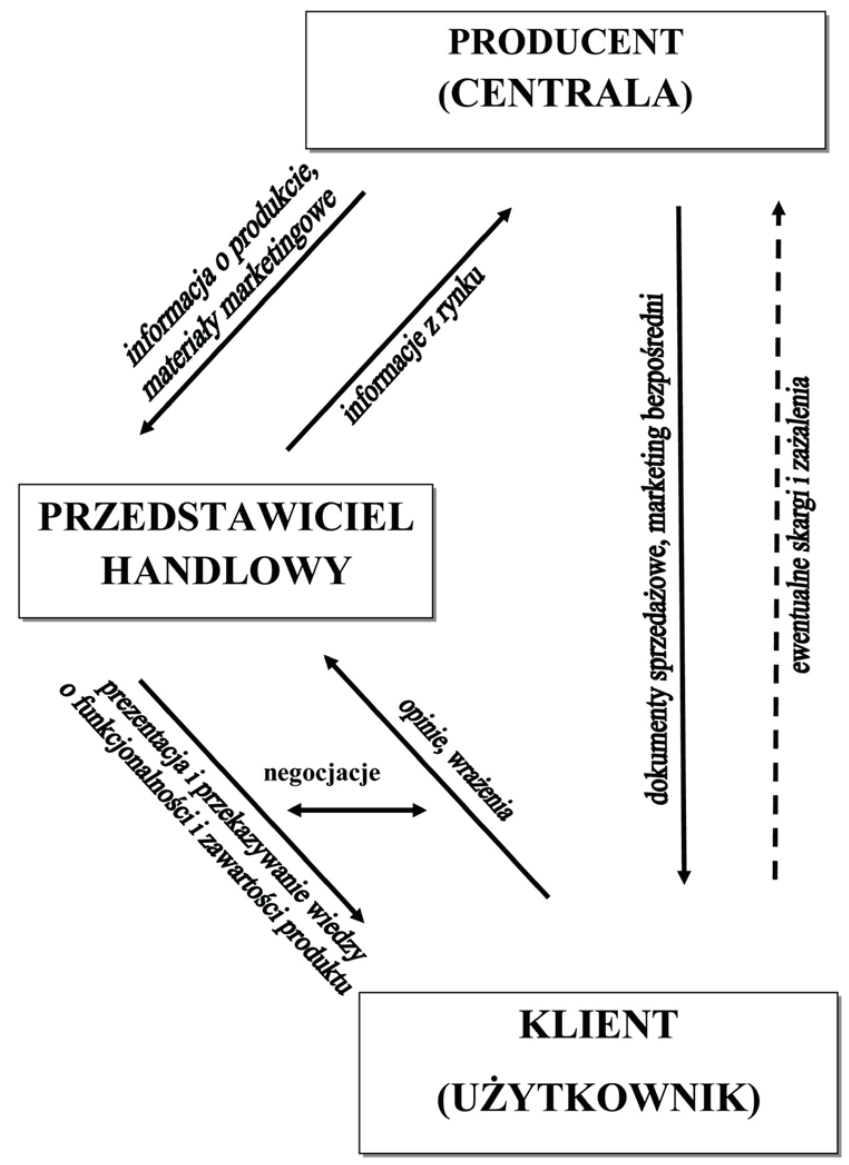

Ryc. 3. Proces dystrybucji Systemów Informacji Prawnej

Źródło: B. Patkowski (2013) 
Klasyczne Systemy Informacji Prawnej dystrybuowane są w Polsce najczęściej w sposób bezpośredni. Oznacza to, że wydawcy posiadają własną sieć przedstawicieli handlowych (konsultantów), którzy na spotkaniach handlowych u potencjalnych klientów prezentują zawartość i funkcjonalność SIP, a następnie negocjują warunki ich sprzedaży (ryc. 3).

Sprzedaż bezpośrednia jest dominującą metodą dystrybucji SIP od początku lat 90. $\mathrm{XX}$ wieku (od początku istnienia SIP) do dnia dzisiejszego. Dominująca rola własnej sieci przedstawicieli handlowych wynika przede wszystkim ze złożonej funkcjonalności SIP i związanej z tym potrzeby bezpośredniego przedstawienia klientowi wartości merytorycznych produktu oraz korzyści związanych z użytkowaniem systemu. W tym celu przedstawiciel handlowy musi pełnić funkcję konsultanta, a więc oprócz typowych umiejętności handlowych powinien posiadać odpowiednią wiedzę z zakresu prawa, ekonomii i biznesu.

Sprzedaż aplikacji elektronicznych z zakresu prawa, biznesu i ekonomii (SIP, serwisy wertykalne, inne mniejsze narzędzia) wzrosła w latach 2001-2012 z 74 mln zł do 416 mln zł, czyli o $562 \%$. Ich udział w globalnej sprzedaży wszelkich publikacji (aplikacje elektroniczne rozumiane są tu jako książki) zwiększył się z 3,5\% w roku 2001 do 15,6\% w roku 2012 (tab. 1).

Tab. 1. Sprzedaż książek (w tym aplikacji elektronicznych) w mln zł

\begin{tabular}{|c|c|c|c|c|c|}
\hline Rok & $\begin{array}{c}\text { Aplikacje } \\
\text { elektroniczne } \\
\text { (prawo, } \\
\text { biznes, } \\
\text { ekonomia) }\end{array}$ & $\begin{array}{c}\text { Książki naukowe } \\
\text { i fachowe } \\
\text { (w tym aplikacje } \\
\text { elektroniczne) }\end{array}$ & $\begin{array}{c}\text { Książki ogółem } \\
\text { (w tym aplikacje } \\
\text { elektroniczne) }\end{array}$ & $\begin{array}{c}\text { Udział aplikacji } \\
\text { elektronicznych } \\
\text { z zakresu } \\
\text { prawa, biznesu } \\
\text { i ekonomii } \\
\text { w sprzedaży } \\
\text { książek } \\
\text { naukowych } \\
\text { i fachowych }\end{array}$ & $\begin{array}{c}\text { Udział aplikacji } \\
\text { elektronicznych } \\
\text { z zakresu } \\
\text { prawa, biznesu } \\
\text { i ekonomii } \\
\text { w sprzedaży } \\
\text { książek ogółem }\end{array}$ \\
\hline 2001 & 74 & 490 & 2100 & $15,10 \%$ & $3,52 \%$ \\
\hline 2002 & 81 & 520 & 2080 & $15,58 \%$ & $3,89 \%$ \\
\hline 2003 & 91 & 525 & 2090 & $17,33 \%$ & $4,35 \%$ \\
\hline 2004 & 98 & 560 & 2210 & $17,50 \%$ & $4,43 \%$ \\
\hline 2005 & 112 & 615 & 2460 & $18,21 \%$ & $4,55 \%$ \\
\hline 2006 & 136 & 655 & 2380 & $20,76 \%$ & $5,71 \%$ \\
\hline 2007 & 181 & 715 & 2600 & $25,31 \%$ & $6,96 \%$ \\
\hline 2008 & 272 & 865 & 2910 & $31,45 \%$ & $9,35 \%$ \\
\hline 2009 & 324 & 940 & 2860 & $34,47 \%$ & $11,33 \%$ \\
\hline 2010 & 356 & 980 & 2940 & $36,33 \%$ & $12,11 \%$ \\
\hline 2011 & 398 & 985 & 2710 & $40,41 \%$ & $14,69 \%$ \\
\hline 2012 & 416 & 975 & 2670 & $42,67 \%$ & $15,58 \%$ \\
\hline
\end{tabular}

Źródło: opracowanie własne na podstawie danych zawartych w Ł. Gołębiewski i P. Waszczyk (2013)

Wśród publikacji fachowych i naukowych SIP orazi inne produkty elektroniczne z zakresu prawa, ekonomii i biznesu stanowią ok. 43\%, rynku (w roku 2001 był to udział ok. 15\%) 
(tab. 1). To, że SIP z roku na rok w coraz większym stopniu zastępują klasyczne publikacje papierowe z zakresu prawa, ekonomii i biznesu jest zjawiskiem naturalnym i związanym z rozwojem technologii. Jednakże ostatnie lata pokazują, że rynek książki jako całość (książki papierowe, e-booki, aplikacje elektroniczne) się skurczył. Od 2010 roku spadło też tempo wzrostu sprzedaży publikacji naukowych i fachowych, a w 2012 roku po raz pierwszy w XXI wieku zanotowano spadek ich sprzedaży. Tego nie można już wytłumaczyć naturalnym procesem przechodzenia klientów z publikacji papierowych na elektroniczne. Wydaje się, że spowolnienie gospodarcze dotknęło także rynek książki. Podobnie jak w przypadku wskaźnika PKB dla Polski, którego tempo wzrostu spadło przede wszystkim w 2012 roku, także rynek książki zareagował z pewnym opóźnieniem w stosunku np. do produkcji sprzedanej przemysłu (ryc. 4). Wielu potencjalnych klientów, minimalizując wydatki na zakup książek, zapewne w większym stopniu zaczęło wykorzystywać darmowe narzędzia zdobywania informacji, takie jak internet. Co prawda naturalny proces przechodzenia wielu czytelników do internetu trwa już od kilku lat i w okresie tym notowano także wzrosty na rynku książki, to jednak w okresie spowolnienia gospodarczego proces ten zapewne pogłębił się.

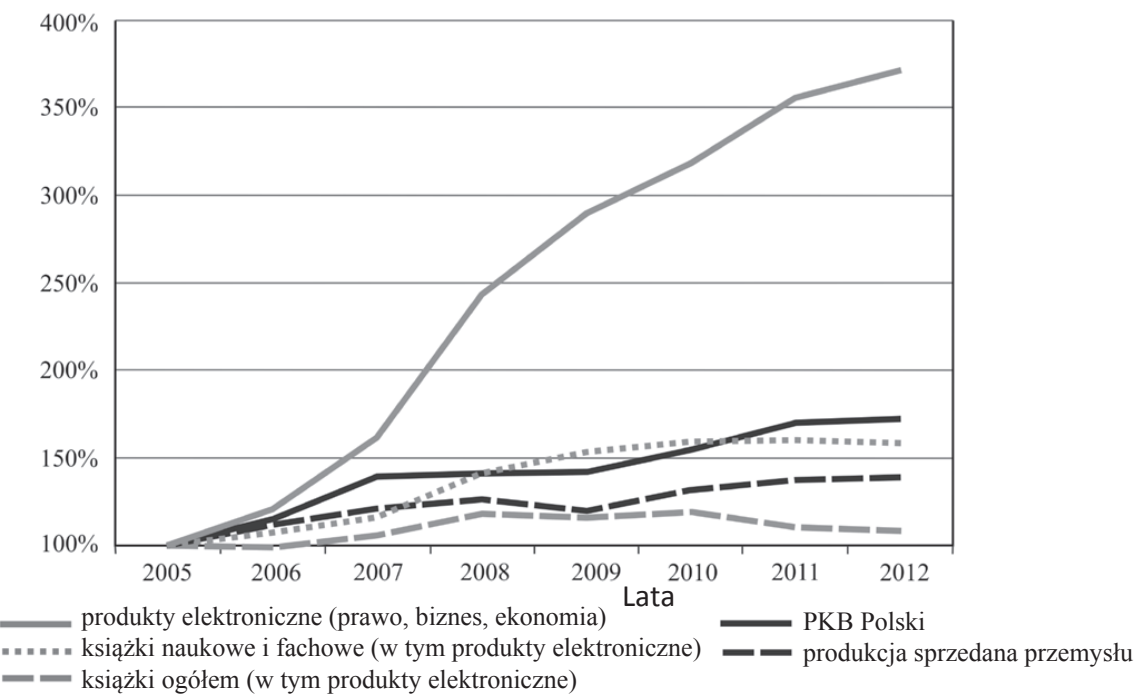

Ryc. 4. Porównanie zmian tempa sprzedaży (rok 2005=100\%) książek ogółem, książek fachowych oraz SIP względem zmian produkcji sprzedanej przemysłu oraz PKB (nominalne)

Źródło: opracowanie własne na podstawie danych: GUS, Ł. Gołębiewski i P. Waszczyk (2013)

Systemy Informacji Prawnej są wyjątkiem na rynku książki pod względem reakcji na spowolnienie gospodarcze. Jest to nie tylko zasługa ich innowacyjności i jakości, ale także w dużym stopniu procesu dystrybucji, który opiera się na sprzedaży bezpośredniej. Wydawcy SIP nie czekają, aż klient do nich przyjdzie i zakupi produkt, lecz sami wykazują się aktywnością. Wiele decyzji zakupowych klientów związanych jest nie tyle z realną sytuacją gospodarczą kraju czy sytuacją osobistą, ale w dużym stopniu z szumem medialnym. 
Słysząc zewsząd informacje o światowym kryzysie, potencjalni klienci na wszelki wypadek wolą zrezygnować z wielu decyzji zakupowych. Na spotkaniach handlowych przedstawiciel wydawcy ma możliwość przeprowadzania merytorycznej dyskusji oraz prezentacji produktu, co znacznie zwiększa szansę sprzedaży.

Rynek aplikacji elektronicznych z zakresu prawa, biznesu i ekonomii to nie tylko segment, który oparł się spowolnieniu gospodarczemu, ale także segment mający duże perspektywy rozwoju.

\section{Podsumowanie}

1. W 2009 roku w Polsce zaobserwowano znaczący wzrost liczby osób zajmujących się sprzedażą bezpośrednią (B2C). Skokowy wzrost zatrudnienia w ramach procesu sprzedaży bezpośredniej przełożył się także na wzrost obrotów w całej branży, w szczególności w 2010 roku.

2. Systemy Informacji Prawnej, których dystrybucja opiera się na procesie sprzedaży bezpośredniej (B2B), są jedynym segmentem w obszarze rynku książki, który wykazuje systematyczny wzrost obrotów, także w okresie spowolnienia gospodarczego.

3. Systemy Informacji Prawnej odegrały i w dalszym ciągu odgrywają znaczącą rolę w kształtowaniu gospodarki opartej na wiedzy w Polsce.

\section{WNIOSKI}

Proces sprzedaży bezpośredniej (B2C i B2B) jest bardzo odporny na wahania koniunkturalne w gospodarce, ponieważ:

a) opiera się na bezpośrednim kontakcie sprzedającego i nabywcy, a jego skuteczność zależy przede wszystkim od umiejętności przedstawicieli handlowych,

b) przedsiębiorstwa sprzedaży bezpośredniej często odgrywają rolę pionierów, którzy tworzą innowacyjne produkty i zdobywają nowe rynki,

c) przedsiębiorstwa sprzedaży bezpośredniej w sposób szczególny dokładają starań, aby ich oferta odpowiadała najwyższym standardom innowacyjnym i jakościowym, ponieważ ich przyszłość zależy od satysfakcji klientów i ich skłonności do związania się z firmą na dłużej.

\section{Literatura \\ References}

Brzozowski, T.T. (2011). Kryzys jako problem filozoficzno-społeczny, Prace Komisji Geografii Przemystu Polskiego Towarzystwa Geograficznego. 17, 261-271.

Gołębiewski, Ł., Waszczyk, P. (2013). Rynek ksiązki w Polsce 2012. Wydawnictwa. Warszawa: Biblioteka Analiz. 
Gorzelak, G. (red.) (2009). Geografia polskiego kryzysu. Kryzys peryferii czy peryferia kryzysu. Warszawa: Euroreg.

Makowska, M. (2010). Sprzedaż bezpośrednia. Tajemnice i mity motywacji pracowników. Toruń: EscapeMagazine.pl. Pozyskano z: http://www.escapemagazine.pl/119374-sprzedaz-bezposrednia

Patkowski, B. (2013). Rozwój Systemów Informacji Prawnej oraz ich rola w kształtowaniu gospodarki opartej na wiedzy (na przykładzie Polski). Prace Komisji Geografii Przemystu Polskiego Towarzystwa Geograficznego, 21, 366-377.

PSSB (2013, 15 listopada). Statystyki Polskiego Stowarzyszenia Sprzedaży Bezpośredniej. Pozyskano z: http://pssb.pl/pssb/sale/statistics,statystyki-sprzedazy-bezposredniej.html

Rachwał, T. (2011). Wpływ kryzysu na zmiany produkcji przemysłowej w Polsce. Prace Komisji Geografii Przemystu Polskiego Towarzystwa Geograficznego, 17, 99-113.

Waszczyk, M., Rodacki, S. (2005). Etos sprzedaży bezpośredniej. Problemy moralne a istniejące uregulowania kodeksowe. W: J. Kubka (red.). Z zagadnień filozofii zarządzania i etyki biznesu. Gdańsk: Wydawnictwo Politechniki Gdańskiej, 97-118.

Wierczyński, G., Wiewiórowski, W.R. (2012). Informatyka prawnicza. Nowoczesne technologie informacyjne w pracy prawników i administracji publicznej. Wyd. 3. Warszawa: Wolters Kluwer Polska

Wiewiórowski, W.R. (2008). Zagrożenia związane z zarządzaniem informacją prawną i prawniczą w środowisku elektronicznym. W: H. Ganińska (red.). Informacja dla nauki a świat zasobów cyfrowych. Poznań: Biblioteka Główna Politechniki Poznańskiej, 82-95.

World Federation of Direct Selling Associations (2013, 16 listopada). Global Statistics. WFDSA. Pozyskano z http://www.wfdsa.org/about_wfdsa/?fa=globalStats

Bartlomiej Patkowski, doktorant Uniwersytetu Pedagogicznego w Krakowie, Instytut Geografii, ukończone studia magisterskie: Uniwersytet Jagielloński, Wydział Biologii i Nauk o Ziemi, Instytut Geografii, Akademia Ekonomiczna w Krakowie (obecnie Uniwersytet Ekonomiczny w Krakowie), Wydział Zarządzania. Zainteresowania badawcze: geografia społeczno-ekonomiczna, przedsiębiorczość, zarządzanie

Bartlomiej Patkowski is a PhD student at the Pedagogical University of Cracow in the Institute of Geography. He received his Master's degree from the Jagiellonian University at the Faculty of Biology and Earth Sciences, from the Institute of Geography at the Cracow Academy of Economics (Cracow University of Economics), in the Faculty of Management. His research interests include: socio-economic geography, entrepreneurship, management.

Witold Jucha, doktorant Uniwersytetu Pedagogicznego w Krakowie, Instytut Geografii, ukończone studia magisterskie: Uniwersytet Pedagogiczny w Krakowie, Instytut Geografii. Zainteresowania badawcze: GIS, kartograficzne metody prezentacji danych.

Witold Jucha is a PhD student at the Pedagogical University of Cracow in the Institute of Geography. He received his Master's degree from the Pedagogical University of Cracow in the Institute of Geography. His research interests include: GIS technology, cartographic methods of visualization of data.

\section{Adres/address:}

Uniwersytet Pedagogiczny w Krakowie

Instytut Geografii

ul. Podchorążych 2, 30-084 Kraków, Polska

e-mail: bioklima@poczta.onet.pl

e-mail: witold.jucha@gmail.com 